Am. Midl. Nat. 143:226-238

\title{
The Contribution of Microarthropods to Aboveground Food Webs: A Review and Model of Bellowground Transfer in a Coniferous Forest
}

\author{
JOHN M. JOHNSTON' \\ U.S. ERA, Office of Research and Development, Ecosystems Research Division, 960 College Station Rd., \\ Athens, Georgia 30605
}

\begin{abstract}
Although belowground food webs have received much attention, studies concerning microarthropods in nondetrital food webs are scarce. Because adult oribatid mites often number between $250,000-500,000 / \mathrm{m}^{2}$ in coniferous forests, microarthropods are a potential food resource for macroarthropod and vertebrate predators of the forest floor. Although the contribution of microarthropods to aboveground food webs has received little attention, sufficient data concerning macroarthropods and vertebrate predators were available at the Savannah River Site (SRS, Aiken, South Carolina) to construct a food web model of the various trophic interactions. To supplement this analysis, literature of microarthropod predation by arthropods and vertebrates was reviewed. This information was incorporated with the existing data to produce a model for taxa occurring in coniferous forests at the SR'S. Because of the diversity and natural history of microarthropod predators, both vertebrate and invertebrate, the resulting web is quite connected and includes transfers to many trophic levels. The diets of arthropods and vertebrates are variable; yet feeding patterns reflect the relative abundance of prey at a place and time. Also, many predators feed on members of their own group. These factors suggest that belowground transfers are deserved of more attention in these and other forest food webs where substantial numbers of detritus feeding invertebrates inhabit the soil/litter interface and are available as prey items. Moreover, this model can he generalized to describe the dynamics of arthropod and vertebrate communities in other coniferous forests. The functioning of terrestrial ecosystems is dependent upon the interrelationships between aboveground and belowground food webs, and transfers of biotic components of the decomposer subsystem to aboveground consumers connect the two subsystems. It is hoped that those consumers traditionally associated with foliage-based food webs be reconsidered, as they may be gaining a proportion of their nutrition from organisms in the detrital pathway.
\end{abstract}

\section{INTRODUGTION}

In forest ecosystems, as in most ecosystems, most net primary productivity flows into the detritall pathway (Coleman and Crossley, 1996). The proportion of flow into the detrital pathway is particularly large in coniferous forests (Knight, 1991). Detrital food webs and their trophic interactions have been studied in various systems and models have been proposed that demonstrate the functional role of various soil invertebrates in patterns of nutrient cycling and decomposition dynamics (Crossley, 1977; Hunt et al., 198'7; Moore et al., 1988; Ingham et al., 1989; Wardle and Yeates, 1993). Fungi and bacteria form the basal consumer trophic level of these food webs and are responsible for the majority of chemical breakdown of plant material across a range of ecosystems. Knight (1991) suggested that, in addition to their role in decomposition in coniferous forests, fungi are also an important food source for invertebrates and vertebrates not associated with the belowground system. As a consequence, energy and materials in the detrital pathway are still accessible to aboveground food webs through the production of sporocarps.

1 Telephone (706) 355-8153; FAX (706) 355-8104; e-mail: johnston.johnm@epa.gov 
Microarthropods, as fungivores and detritivores, are another potential link from the detrital pathway to the aboveground ecosystem component. Kajak et al. (1991) proposed that in ecosystems where mineralization of organic matter is slower, and organic matter inputs tend to accumulate, the proportion of flow into predators is greater. They further suggested that in forests with a mor humus (i.e., the well stratified layers of organic matter in coniferous forests) predatory activity accounts for over $50 \%$ of the total soil respiration (Kajak et al., 1991). As prey items, oribatid mites (Acari: Oribatida) and springtails (Insecta: Collembola) are different extremes in resource quality. Surface-dwelling springtails are softbodied but highly mobile "plankton of the soil" (Aoki, 1973), whereas oribatids are protected by an exoskeleton but are quite easily captured by predators. The great morphological diversity of the Oribatida is believed to be the result of defense adaptations to predation. Oribatids have a hard integument and have evolved numerous structures for defense, including winged projections that shield the legs and venter (called pteromorphs). The pteromorphed jackknife mites (Phthiracarus, Oribotritia spp., etc.) have a defense behavior that is quite effective: like sowbugs (Isopoda), they can completely retract their legs and sensory organs and form a hard, nearly impenetrable ball. These defenses are most effective against microarthropod predators such as the Mesostigmata and pseudoscorpions. Such adaptations become completely ineffective, though, against much larger mandibulate arthropods such as ants and carabid beetles.

Oribatid mites were the most abundant soil microarthropod group in six Loblolly pine (Pinus taeda) forests of varying ages at the Savannah River Site (SRS), comprising two thirds of the abundance of soil and litter fauna (Johnston, 1996). Even in the intensively managed forests of the SRS, oribatid abundance reached nearly $60,000 / \mathrm{m}^{2}$ in the litter layer alone (Johnston, 1996). However, populations of mature Oribatid mites can reach 250,000$500,000 / \mathrm{m}^{2}$ in coniferous forests (Coleman and Crossley, 1996). Because of their availability, these arthropods may be an important food source for other fauna. Oribatids are one of the few soil microarthropods to sequester quantities of calcium in their calcareous exoskeletons (Coleman and Crossley, 1996). Collembola accumulate both potassium and calcium, to the extent that potassium tissue concentrations can reach 15 times the concentrations of that observed in leaf litter (Roth-Holzapfel, 1990).

The ecology and natural history of many of the taxa at the Savannah River Site (SRS, Aiken, South Carolina) have been the subject of study for several decades. To date, though, there has been no attempt to integrate the available information for the terrestrial subsystems and present an analysis of the belowground contribution to aboveground patterns of consumption. In addition to the existing data, I have reviewed the literature for instances of microarthropod predation, searching specifically for cases involving oribatids and collembolans. Because these taxa are typically the most numerous forest arthropods, and due to their differences as prey types, it is hoped that these groups will prove to be useful surrogates for microarthropods as a whole. Also, a greater diversity of predators may be involved as a result of feeding preferences and specialized modes of predation. Confirmed feeding relationships, whether from the literature or by cited authority, were used to construct the food web model for these forests. By demonstrating how microarthropods are components of a nondetrital food web, different functional relationships will be apparent in this forest ecosystem that can be generalized to other systems. Specifically, detritus based food webs are not isolated from aboveground consumption; and, aboveground predators are quite capable at feeding at the belowground interface, making use of that majority of ecosystem production that has become a part of the detrital pathway. 


\section{LITERATURE REVIEW AND SURVEY}

In addition to the general ecology and soil biology literature, volumes of Herpetologica '(Vol. 1-51, spanning 1936-1995) and the Journal of Herpetology (Vol. 1-29,1968-1995) were reviewed for diets of reptile and amphibian species that include these microarthropods. Authors that listed "mites" as a group were included, as oribatids are typically the most abundant constituents of this group. Burton (1976) separated oribatid and nonoribatid prey when enumerating gut contents of salamanders, and oribatids were more numerous in every instance. Records where acarids were lumped under the larger classification of "arachnids" were not included.

Several researchers at the SRS provided information from their research. Jim Hanula (U.S. Forest Service) maintained an extensive macroarthropod pitfall trapping experiment on a range of forest types and successional ages. This trapping, in addition to funnel and flight intercept traps on trees, was implemented to study the abundances and seasonal dynamics of possible food items of the red-cockaded woodpecker (Hanula and Franzreb, 1995). Michael Draney (Savannah River Ecology Laboratory, SREL) has been working with the Araneae at the SRS for a number of years and contributed information concerning natural history and significance of roving and soil-dwelling spiders in this system.

\section{ARTHROPOD PREDATORS OF Microarthropods}

Mesostigmatid. mites (Arrachnida, Acari) are known to be predators of both Collembola and oribatids (Eisenbeis and Wichard, 1987). Pseudoscorpions (Arachnida, Pseudoscorpiones) also prey on the microarthopods in general. Their diet consists of Collembola, mites and nematodes (Eisenbeis and Wichard, 1987). Doubletails (Insecta, Diplura) consume the smallest soil arthropods (Eisenbeis and Wichard, 1987), though the japygids mainly prey on Collembola (Simon, 1964). Dermaptera (earwigs) are also predators of both of these microarthropods (Gunther and Herter, 1974).

As generalist predators, spiders (Arachnida, Araneae) also feed on microarthropod pop ulations (Wise, 1993). Roving wolf spiders (Lycosidae) are predators of the soil community, and Collembola are one of the main prey groups (Nentwig, 1987). Certain groups are considered soil dwellers: purse-web spiders (Atypidae), sack spiders (Clubionidae), tube spiders (Agelenidae), soil spiders (Hahniidae) and dwarf spiders (Micryphantidae). These groups, and others, are likely to feed on microarthropods, though there are apparently no published accounts to corroborate this. The relatively small bodied litter dwelling Linyphiidae are often abundant in the temperate zone and include mites and springtails in their diet (Sunderland et al., 1986). Sunderland et $a l .(1986)$ found that Collembola accounted for $99 \%$ of the number of prey caught in their study.

Another arachnid group, harvestmen (Arachnida, Opiliones), catch mites and Collembola (among other prey) on the forest floor (Eisenbeis and Wichard, 1987). Martens (1978) recorded Siro duricoriw and S. rubens burrowing into the soil, sometimes to a depth of 1 $\mathrm{m}$, preying on mites and Collembola. Centipedes (Myriapoda, Chilopoda), such as Lithobius spp., prey mostly on small insects. It is likely that these include mites and collembolans (Eisenbeis and Wichard, 1987).

Many beetles (Insecta, Coleoptera) have specific adaptations for capturing microfauna. Some carabids have evolved a successful visual hunting strategy for fast moving prey like Collembola (Bauer, 1981; 1982a; 1985a). Loricera pilicornis and two species of Leistus use modified seta to enclose a springtail during an attack. These traps are constructed from enlarged seta on the antennae and ventral surfaces of the head (Bauer, 1982b; Bauer, 1985b; Hintzpeter and Bauer, 1986). Larvae of the Scydmaenidae (ant beetles) resemble woodlice 
and are oribatid specialists. One such species is Cephennium thoracicum, which curls around the captured mite and kills by biting with stiletto-like mandibles and injecting it with digestive juices. Another species, C. austriacum, picks up mites with its mandibles and can even walk around carrying the prey (Schuster, 1966a; 1966b).

According to Edward $\mathrm{O}$. Wilson, ants (Insecta, Hymenoptera) "eat oribatids like popcorn" (in Coleman and Crossley, 1996), though recorded accounts are rare. In most habitats ant workers are the chief predators of insects and spiders. This is due to the high abundance and activity of these omnivorous foragers (Hölldobler and Wilson, 1994). However, some species are more efficient predators of microarthropods. For example, ants in the genus Acanthognathus snare springtails with large, trap-like mandibles (Hölldobler and Wilson, 1994). Masuko (1994) also described the specialized oribatid feeding behavior in two species of Myrmecina: $M$. graminocola nipponica and $M$. flava. These small ants-3 $\mathrm{mm}$ and 2.5 $\mathrm{mm}$ long respectively-also accepted entomobryonorph collembolans, beetle larvae ( $T e-$ nebrio molitor and Tribolium confusum), geophilomorph centipedes and terrestrial amphipods (Talitridae) in the laboratory. Masuko (1994) also noted predation on oribatids by Adelomyrmex sp.

\section{Vertebrate Predators of Microarthropods}

Specialization on mites by frogs was evaluated by Simon and Toft (1991). Many small dendrobatids in the genus Minyobates consume mites with a higher frequency than expected based on the relative frequency of mites compared to the total possible prey fauna. There are a number of tropical mite specialists (with \% of total number of prey diet in parentheses): Atelopus oxyrhynchus (32.2\% prey), Pseudophryne corroboree juveniles (46\%) and subadults $(25 \%)$, Rana arvalis $<26 \mathrm{~mm}(36.6 \%)$ and $R$. temporaria $<30 \mathrm{~mm}(33.4 \%)$. As illustrated by these values, the proportion of small-bodied prey is often much greater for the smaller frogs and their juvenile stages. In the neotropics mites are the prey equivalent of ants, though at the smaller end of the size continuum (Simon and Toft, 1991). These authors hypothesize that in the tropics mites are suitable prey for specialists because they are abundant and slow-moving. An important trade-off, though, is that mites contain a higher proportion of chitin and are more difficult to ingest. Simon and Toft (1991) also demonstrated that mite-eating amphibians are not limited to the neotropics; many occur in North America. Mites were found in $80 \%$ of the stomachs of the toad Bufo americanus and made up $16 \%$ prey (by number) in $8-12 \mathrm{~mm}$ size individuals. For another species, $B$. woodhousei, mites occurred in $14 \%$ of toadlet stomachs (Simon and Toft, 1991). Microarthropods were found in the diet of the oak toad, B. quercicus, and mites ranked fourth in overall abundance after ants, beetles and spiders (Hamilton, 1955). Examples of mite-feeding by various sizes of hylid frogs are Pseudacris triseriata $(10-15 \mathrm{~mm}$ size class, $39 \%$ of stomachs sampled), $P$. nigrita (20-32 mm size class, $11 \%$ stomachs sampled) and Acris crepitans (25-30 mm size class, $12 \%$ stomachs sampled) (Simon and Toft, 1991). Other researchers have recorded mites and Collembola in the diet of the cricket frog, Acris crepitans (Johnson and Christiansen, 1976; Labanick, 1976). Labanick (1976) found that in 268 frogs sampled microarthropods made up over $20 \%$ of the total number of food items. Labanick (1976) also determined that prey selection was not as important as prey availability for the cricket frog.

Salamanders such as Notophthalmus viridescens (eastern red-spotted newt) are often voracious predators of oribatids and Collembola and are one of the few species that continue to eat mostly microarthropods as adults (Hamilton, 1932; Burton, 1976; Norton and MacNamara, 1976; MacNamara, 1977). It has been estimated that "a hungry eft may consume 2000 springtails" (Behler and King, 1979). The plethodontids (woodland salaman- 
TABLE 1.-Arthropod and vertebrate predators of microarthropods. (Sources: $\mathrm{A}$ and M, $1967=$ . Anderson and Martino, 1967; Draney* = M. Draney, pers. comm.; Edwards = M. L. Edwards, pers. comm.; $\mathrm{E}$ and W, 1987 = Eisenbeis and Wichard, 1987; G and S, 1991 = Gibbons and Semlitch, 1991; Hanula $\dagger=$ J. Hanula, pers. comm.; Johnston $\ddagger=$ Johnston, 1996; M and S, $1980=$ McMillan and Semlitsch, 1980; N and M, $1976=$ Norton and MacNamara, 1976; P and T, $1974=$ Powders and Tietjen, 1974; S and T, $1991=$ Simon and Toft, 1991; Sunderland, $1986=$ Sunderland $e$ a al., 1986)

\begin{tabular}{|c|c|c|c|}
\hline & Oribatida & Collembola & Occurs at S.R.S. \\
\hline \multicolumn{4}{|l|}{ Microarthropods } \\
\hline $\begin{array}{l}\text { Diplura } \\
\text { Japygidae } \\
\text { Mesostigmata } \\
\text { Opiliones (Harvestmen) } \\
\text { Pseudoscorpiones }\end{array}$ & $\begin{array}{l}E \text { and } W, 1987 \\
E \text { and } W, 1987 \\
E \text { and } W, 1987 \\
E \text { and } W, 1987\end{array}$ & $\begin{array}{l}\text { Simon, } 1964 \\
\text { E and W, } 1987 \\
\text { E and W, } 1987 \\
\text { E and } W, 1987\end{array}$ & $\begin{array}{l}\text { Johnston } \ddagger \\
\text { Johnston } \ddagger \\
\text { Johnston } \ddagger \\
\text { Johnston } \ddagger \\
\text { Johnston } \ddagger\end{array}$ \\
\hline \multicolumn{4}{|l|}{ Macroarthropods } \\
\hline $\begin{array}{l}\text { Lithobiidae (Centipedes) } \\
\text { Lithobius sp. } \\
\text { Coleoptera (Beetles) } \\
\text { Loricera pilicornis } \\
\text { Pselaphidae } \\
\text { Ptiliidae } \\
\text { Scydmaenidae (Ant lions) }\end{array}$ & & $\begin{array}{l}\text { E and W, } 1987 \\
\text { Bauer, } 1981 \\
\text { Park, } 1947 \\
\text { Riha, 1951 } \\
\text { Schuster, 1966a,b }\end{array}$ & $\begin{array}{l}\text { Hanula† } \\
\text { Hanula } \\
\text { Hanula† }\end{array}$ \\
\hline \multicolumn{4}{|l|}{ Spiders } \\
\hline $\begin{array}{l}\text { Linyphiidae } \\
\text { Lycosidae (Wolf spiders) } \\
\text { Pardosa sp. } \\
\text { Pirata sp. } \\
\text { Schizocosa sp. (imm.) } \\
\text { Hanhniidae }\end{array}$ & & $\begin{array}{l}\text { Sunderland, } 1986 \\
\text { Draney* } \\
\text { Draney* } \\
\text { Draney* } \\
\text { Draney* }\end{array}$ & $\begin{array}{l}\text { Draney* } \\
\text { Draney* } \\
\text { Draney* } \\
\text { Draney* } \\
\text { Draney* }\end{array}$ \\
\hline \multicolumn{4}{|l|}{ Ants } \\
\hline \multicolumn{4}{|l|}{ Reptiles } \\
\hline \multicolumn{4}{|l|}{ Salamanders } \\
\hline $\begin{array}{l}\text { Batrachoseps attenuatus } \\
\text { Eurycea longicauda } \\
\text { Notophthalmus viridescens } \\
\text { Plethodon glutinosus } \\
\text { P. cinereus } \\
\text { Desmognathus fuscus } \\
\text { E. bislineata } \\
\text { Gyrinophilus porphyriticus } \\
\text { E. quadridigitata }\end{array}$ & $\begin{array}{l}\text { Adams, } 1968 \\
\text { A and } M, 1967 \\
\mathrm{~N} \text { and } \mathrm{M}, 1976 \\
\mathrm{P} \text { and } \mathrm{T}, 1974 \\
\text { Burton, } 1976 \\
\text { Burton, } 1976 \\
\text { Burton, } 1976 \\
\text { Burton, } 1976 \\
\mathrm{M} \text { and } \mathrm{S}, 1980\end{array}$ & $\begin{array}{l}\text { Adams, } 1968 \\
\text { A and M, } 1967 \\
\text { MacNamara, } 1977 \\
\text { P and T, } 1974 \\
\text { Burton, } 1976 \\
\text { Burton, } 1976 \\
\text { Burton, } 1976 \\
\text { Burton, } 1976 \\
\text { M and S, } 1980\end{array}$ & $\begin{array}{l}G \text { and } S, 1991 \\
G \text { and } S, 1991 \\
G \text { and } S, 1991\end{array}$ \\
\hline \multicolumn{4}{|l|}{ Frogs } \\
\hline $\begin{array}{l}\text { Acris crepitans } \\
\text { Pseudacris nigrita } \\
P . \text { treseriata } \\
\text { Rana clamitans } \\
\text { R. sphenocephala }\end{array}$ & $\begin{array}{l}S \text { and } T, 1991 \\
S \text { and } T, 1991 \\
S \text { and } T, 1991 \\
S \text { and } T, 1991 \\
S \text { and } T, 1991\end{array}$ & & $\begin{array}{l}G \text { and } S, 1991 \\
G \text { and } S, 1991 \\
G \text { and } S, 1991 \\
G \text { and } S, 1991 \\
G \text { and } S, 1991\end{array}$ \\
\hline
\end{tabular}


TABLE 1.-Continued

\begin{tabular}{lccc}
\hline \hline & Oribatida & Collembola & Occurs at S.R.S. \\
\hline Toads & & & \\
$\begin{array}{l}\text { Bufo terrestris } \\
\text { B. quercicus }\end{array}$ & S and T, 1991 & Hamilton, 1955 & G and S, 1991 \\
B. woodhousei & S and T, 1991 & & G and S, 1991 \\
\hline
\end{tabular}

ders) are also microarthropod consumers. Mites and Collembola are consumed regularly by Batrachoseps attenuatus (Adams, 1968), Eurycea longicauda (Anderson and Martino, 1967), Plethodon cinereus, Desmognathus fuscus, E. bislineata, Gyrinophilus porphyriticus (Burton, 1976) and E. quadridigitata (McMillan and Semlitsch, 1980; Powders and Cate, 1980). The relative abundance of the various invertebrates was directly correlated to the proportion of each kind taken by the slimy salamander, Plethodon glutinosus (Holman, 1955). According to Davidson (1956), availability is the single most important factor governing the feeding habits of this species. Comparisons of Plethodon glutinosus stomach content data from other locations support this assertion. Diets switched apparently from a majority of ants and coleoptera $(42 \%$ and $18 \%$ by biomass respectively) (Davidson, 1956) to diplopods and coleoptera ( $55 \%$ and $8 \%$ by biomass) at one site and diplopods, formicids and chilopods (31\%, 10\%, and $9 \%$ by biomass) at yet another (Powders and Tietjen, 1974). Burton (1976) was one of the few to distinguish between oribatid and nonoribatid mites in published diets; and it is worth mentioning that in every case oribatids were most numerous, often by a margin of 3 to 1 .

\section{A FOOD WEB AT SRS}

A synthesis of literature compiled in the present study is summarized in Table 1 , and the cited authority confirms the presence of each group or species. Many of the invertebrate and vertebrate species identified as Oribatida and Collembola predators occur at the SRS. The Coastal Plain is especially diverse with regard to the herpetofauna, and of amphibians verified as mite feeders in the literature, 13 species occur at the Savannah River Site. Information on many taxa is incomplete or nonexistent, however, and these will be discussed.

Extensive pitfall trapping at SRS revealed that ants are the most numerous animal group in planted and natural pine stands of a variety of ages (often $90 \%$ or more of the total number of arthropods), especially the genera Prenolepis, Aphaenogaster, Crematogaster and Solenopsis (in declining order) (J. Hanula, pers. comm.). Van Pelt (1966) and Van Pelt and Gentry (1985) examined the activity and density of ants in old fields at the SRS, finding Dorymyrmex pyramicus to be the most abundant species and confirming the presence of the genus Myrmecina. Dorymyrmex pyramicus was a very general feeder that attacks invertebrates and even frogs and toads (Van Pelt, 1966).

The overall effect of ant predation on microarthropods is assumed to be important (Hölldobler and Wilson, 1994), but is difficult to state in exact terms. Because of the patchy distribution of ant species, the effect of any one taxon is probably unimportant. However, due to the fact that ants are overall quite numerous, and most carnivorous species consume roughly the same resources, the net effect of all species can be considerable. Variables that influence the predation intensity of a colony include colony status, season and foraging efficiency. Some ants, such as the tribe Dacetini, are very efficient predators and have a much greater effect per individual on prey populations than others ( $R$. Carroll, pers. comm.). In addition to seasonal variation in colony activity, energetic requirements change 
during the lifetime of a colony. Protein requirements are higher in growth phases due to developing larvae. The carbohydrate requirements of a colony are higher when it becomes established and requires maintenance instead.

With spiders the determining factor in prey type is the relative size of the predator. Though the smaller linyphiids eat mites, they are probably not the main diet. Most grounddwelling spiders do, however, consume springtails at some stage of development. Adult lycosids (wolf spiders) are unlikely to consume prey as small as springtails, whereas immatures may eat little else (M. Draney, pers. comm.). An example of this is the genus Schizocosa, a relatively abundant lycosid at the SRS ( $\mathrm{J}$. Hanula, pers. comm.). Adults of smaller taxa that feed on Collembola include Pardosa, Pirata (also wandering spiders) and the Hahniidae.

Beetles are also an abundant, and highly diverse, group in SRS pine forests (J. Hanula, pers. comm.). Many if not most carabid larvae and adults are opportunistic and polyphagous (saprophages, macrophytophages, carnivores) and may feed on almost any soil invertebrate (Ekschmitt et al., 1997). Most staphylinids are also predators of microarthropods and macroarthrpods (Ekschmitt et al., 1997). Not enough natural history information is available to make definitive statements of the impact of coleopteran predators, though their feeding activities may be considerable (Eisenbeis and Wichard, 1984). For example, Carabus auratus can consume up to two and a half times its own body mass. The average daily food consumption for a $0.640 \mathrm{~g}$ beetle was $0.875 \mathrm{~g}$ (Scherney, 1959; 1961).

With the exception of Terrapene carolina (box turtle), which feeds on invertebrates (Martof et al., 1980), few of the reptile diets have been researched with any degree of detail. Much less is known about the habits of the immature stages of the same reptiles. Hatchling turtles feed upon a range of small invertebrates, including Collembola (M. L. Edwards, pers. comm.), but diets have not been published. This lack of information seems to be a bias on the part of herpetologists, rather than a lack of microarthropod feeders in the Reptilia, because many species of lizard are both insectivorous and common to soutiesstern pine forests. This includes anoles (Anolis carolinensis), fence lizards (Sceloporus undulatus) and skinks (Scincella lateralis, Eumeces fasciatus, E. inexpectatus and E. laticeps) (Gibbons and Semlitsch, 1991). Vitt and Cooper (1986) provided the only information in this survey for a scincid, Eumeces laticeps, and it is one of the few lizards that hunts (mostly for gryllids and blattids) by actively flushing prey from refugia in the leaf and woody litter. This species is also cannibalistic on all other lizard taxa that it can manage, due to its rather large size compared with other skinks (Douglas, 1965). Though adult lizards feed mainly on macrofauna such as crickets, grasshoppers and roaches, the diets of immatures almost certainly include microarthropods.

The conclusion reached by many herpetologists is that diet is a direct reflection of prey availability in the environment (Hamilton, 1955; Holman, 1955; Davidson, 1956; Burton, 1976; Labanick, 1976; MacNamara, 1977). Though an occasional species may have a specialized diet, a catholic feeding habit is characteristic of most toads, frogs and salamanders. McMillan and Semlitch (1980) found a very dramatic example of this for the dwarf salamander, Eurycea quadridigitata, in two different sampling locations at the SRS. Mites accounted for $24 \%$ of the number of prey at one site, while Collembola were taken in huge quantities at another site, numbering several thousands of individuals (and $97 \%$ of the total prey).

A hypothesized food web is depicted in Figure 1. Information for the remaining predators in the system was compiled from a variety of sources. The narrow-mouthed toad (Gastrophryne carolinensis, moved from the genus Microhyla) appears to be an ant specialist, to the extent that some authors labeled it an ectoparasite of ant colonies (Wood, 1948; Holman, 


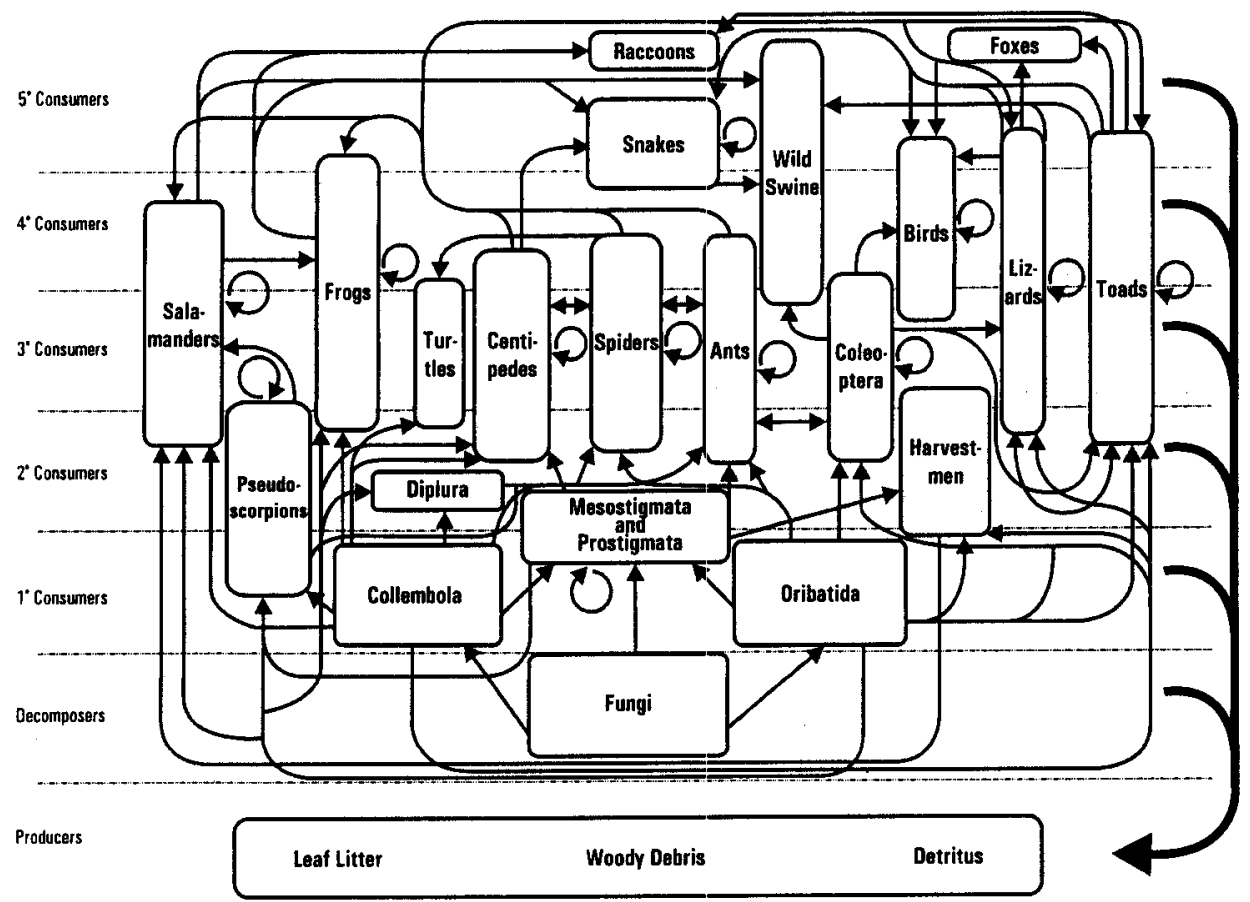

FIG. 1.-An aboveground food web with belowground connections in a coniferous forest. The positioning and vertical extent of each component corresponds to the various trophic levels for each type. Plant and animal matter of different types and in various stages of decay compose a portion of the production for this system. This material enters the web primarily through the action of fungal species. Note that box width (horizontal extent) is for display purposes only and is not meant to imply qualitative or quantitative comparison

1958). The diet of Bufo woodhousei consists mostly of Coleoptera and Hymenoptera (Bush and Menhinick, 1962). The spadefoot toad, Scaphiophus h. holbrookii, feeds primarily on Coleoptera and Hymenoptera and Arachnida to a lesser degree (Pearson, 1955). Snakes feed on a number of salamanders, lizards, frogs, toads and other snakes (Hudson, 1947; Chenoweth, 1948; Orleb, 1951; Healy, 1953; Behler and King, 1979; Martof et al., 1980; Conant and Collins, 1991). One snake species is known to be an arthropod feeder, the southeastern crowned snake Tantilla coronata, and it consumes primarily centipedes as an adult. It is also the most frequently captured snake in pitfall traps along drift fences at SRS (Gibbons and Semlitsch, 1991).

Wild swine (Sus scrofa) feed on soil invertebrates and vertebrates (Singer et al., 1984). Raccoons (Procyon lotor) and the red fox (Vulpes vulpes) are also predators of reptiles and amphibians (Schaaf and Garton, 1970; Skeen et ai., 1993). Insectivorous birds at the SRS include the red-cockaded woodpecker (Picoides borealis) and the Carolina wren (Thryothorus ludovicanus) (Skeen et al., 1993; Hanula and Franzreb, 1995). The broad-winged hawk (Buteo platypterus) is a reptile (snake) specialist (Skeen et al., 1993).

A majority of predators-be they invertebrate, amphibian, reptilian or mammalian-are opportunistic feeders on a wide range of prey types and size classes. Patterns of prey consumption change not just seasonally but also locally based on availability. This generalization 
likely holds for all such taxa where data were scarce. For the purpose of depicting a food web (Fig. 1) this leads to a highly connected web of predators. Many of the groups (ants, spiders, herpetofauna, etc.) prey frequently on members of the same group, and this is depicted by recycling arrows.

Oribatids are the most numerous microarthropods in forests of the SRS, and ants are by far the most abundant macroarthropods. A significant transfer of microarthropod biomass through the food web appears to be through ant predation. Ants are significant predators of arthropods in general, and these Hymenoptera are sufficiently abundant to be a component of a variety of vertebrate diets. Quantification of the strength of this link can be achieved only through experimental manipulations of ant abundance. However, most of the experimental work to test such aboveground and belowground relationships involves spiders and Collembola as experimental subjects (see Wise, 1993). The direct and indirect effects of ant predation on oribatid mites follow a similar reasoning, and the evidence will be discussed in the following section. Augmentation and removal studies of predators and prey groups could be used to study the trophic effects in this forest ecosystem (in both directions).

Although diets for many likely microarthropod predators were not found in the literature, it is probable that various lizard and snake species are indeed making use of microarthropods as immatures. Many adult toads, frogs and salamanders consume quantities of ants when they are abundant. Oribatid mites are even more abundant prey than ants and would serve as a likely resource for the smaller herpetofauna and those in early stages of development. Although information is scarce for this it does seem likely, and the similarity between oribatids and ants as prey types has been suggested (Simon and Toft, 1991).

\section{DiscitsSION}

There is evidence to support the conclusion that a considerable proportion of the belowground biomass in this forest ecosystem is transferred to aboveground predators. Moulder and Reichle (1972) estimated that spiders consumed $44 \%$ of the mean annual standing crop of all soil invertebrates using concentration and turnover rates of radioactive cesium in a forest floor community. Wise (1993) considers this estimate to be conservative since many prey were not "suitable" because of size and palatability. Many others have similarly concluded that spiders are important predators in forest ecosystems (Reichle and Crossley, 1965; Norton, 1973; Manley et al., 1976; Wise, 1993). Ekschmitt et al. (1997) reviewed the potential of the polyphagous predators, i.e., spiders, carabids and staphylinids, as biological control measures in agroecosystems due to their ability to significantly affect the population dynamics of plant and detrital feeding invertebrates.

There is interest in the indirect effects of forest floor predators as well. However, quantifying the effect on belowground communities and the resultant ecosystem processes has proven to be extremely difficult. Kajak et al. (1991) attempted to relate the indirect effect of predator densities (arachnids, carabids, staphylinids and hymenopterans) on decomposition rates and patterns of nutrient cycling ( see Wise, 1993). The mechanism of interest to these authors is the reduction of numbers of detrital feeding invertebrates (e.g., oribatid mites and collembolans) via predation on the soil surface. These authors demonstrated an increase in decomposition rate in predator exclusion devices with the implication that both microarthropod densities and the rate of decomposition were influenced by spider (and other) predators of the soil/litter interface.

Wise (1993) also reviewed other experimental evidence (e.g., Clarke and Grant, 1968) with regard to the impact of spiders on microarthropod densities. To date, however, no one has directly manipulated invertebrate predator densities in field experiments and the dif- 
ficulties in designing a study to test such an effect are manifold. The design challenges include the need for sufficient replication of experimental units (Clarke and Grant, 1968) and the effect of caging predators and their prey (Kajak et al., 1991). Furthermore, Wise (1993) urged experiments with open controls, larger experimental units and longer durations.

The forests of the Savannah River Site, though an agricultural crop (plantation), foster a diversity of predator taxa, with a diversity of species in each group. Ekschmitt et al. (1997) offered recommendations for those methods which foster higher abundance and diversity of polyphagous predators in agroecosystems. These include: (1) reduction of agricultural practices (e.g., plowing and harvest), (2) maintenance of overwintering sites and (3) the use of intercropping and mulching (for a diversity of habitat structure and refugia). Interestingly, in these managed pine plantations that are harvested every $25 \mathrm{y}$ (on average) there exists a diversity of ground cover, shrubs, large woody debris, standing dead trees and gaps in canopy cover that are succeeded by hardwood regrowth. Though a passive type of management for the fauna under consideration, it has the effect of supporting an abundant and dynamic community. Summerhayes and Elton (1923) presented one of the few integrated food webs that details the feeding interactions between detritivorous microarthropods and aboveground and aquatic biota. In their Arctic ecosystem, predators of microarthropods included an arachnid and three species of birds. Clearly, the number of predators in the current forest ecosystem results in a greater amount of interaction between the subsystems as well as more complicated dynamics. As discussed, the interrelationship between aboveground and belowground systems has been approached from few directions with various intents. Food webs can serve as the basis for model development of material and energetic flows and are appropriate tools for management and decision making. Although knowledge of the linkages and strengths of multispecies interactions in a particular system is often a prerequisite for better conservation of species, such comprehension has proven quite difficult to achieve. There is also the difficulty that the strengths of various trophic interactions and even food web membership can change dramatically through time (Tavares-Cromar and Williams, 1996). Though the SRS is one system that has been studied in some detail, many questions still remain. Moreover, the potential significance of microarthropod predators will differ as a function of food web composition, season and those taxa favored by the prevailing type of management. Also, although soil nematodes and enchytraeid worms have not been discussed here, they may also be important components of the detrital community in aboveground food webs. The contribution of microarthropods, especially oribatid mites, to aboveground food webs is apparent. Many vertebrates feed on them directly, and those fauna that prefer larger prey items are often consuming various arthropod predators of the microfauna. It is hoped that this review stimulates discussion of this apparently overlooked, but important, interface between the surface and subsurface of this, and possibly other, forest ecosystems.

Acknowledgments.-The author would like to thank the following individuals for their assistance in the form of helpful comments and sharing of their research findings: Ron Carroll (Institute of Ecology), Mary Lang Edwards (Erskine College), Mike Draney (SREL), J. Whitfield Gibbons (SREL), Jim Hanula (U.S.F.S.), Roy Norton (SUNY) and David Walter (Univ. of Queensland). This research was initiated while the author was completing his Ph.D. Dissertation at the University of Georgia, Institute of Ecology. The U.S.F.S. Southeast Forest Experiment Station, through a cooperative agreement to the University of Georgia, provided the initial funding for this work. John Blake, Jim McMinn and Marilyn Buford are thanked for their support of this research at the SRS. The comments of M. Craig Barber (U.S. EPA) and two anonymous reviewers improved the manuscript. 


\section{Literature Gited}

ADAMS, D. R. 1968. Stomach contents of the salamander Batrachoseps attenuatus in California. Herpetologica, 24:170-172.

ANDERSON, J. D. AND P. J. MARTINo. 1967. Food habits of Eurycea longicauda longicauda. Herpetologica, 23:105-108.

AOKI, J. 1973. Soil Zoology. Hokuryu-kan, Tokyo. 814 p.

BAuer, T. 1981. Prey capture and structure of the visual space of an insect that hunts by sight on the litter layer (Notiophilus biguttatus F., Carabidae, Col€optera). Behav. Ecol. Sociobiol., 8:91-97. 1982a. Prey capture in a ground-beetle larva. Anim. Behav., 30:203-208.

1982b. Predation by a carabid beetle specialized for catching Collembola. Pedoliologia, 24:169179.

1985a. Different adaptation to visual hunting in three ground beetle species of the same genus. J. Insect Physiol., 31:593-601.

1985b. Beetles which use a setal trap to hunt springtails: The hunting strategy and apparatus of Leistus (Coleoptera, Carabidae). Pedobiologia, 28:275-287.

BeHLER, J. L. AND F. W. KING. 1979. The Audubon Society field guide to North American reptiles and amphibians. Alfred A. Knopf, New York. 718 p.

Burton, T. M. 1976. An analysis of the feeding ecology of the salamanders (Amphibia, Urodela) of the Hubbard Brook Experimental Forest, New Hampshire. J. Herpetol., 10:187-204.

BuSH, F. M. AND E. F. MENHINICK. 1962. The food of Bufo woodhousei fowleri Hinckley. Herpetologica, 18:110-114.

ChENOWETH, W. L. 1948. The birth and behavior of young copperheads. Herpetologica, 4:162.

GlaRKE, R. D. AND P. R. GRANT. 1968. An experimental study of the role of spiders as predators in a forest litter community. Part I. Ecology, 49:1152-1154.

Coleman, D. C. And D. A. Crossley, JR. 1996. Fundamentals of soil ecology. Academic Press, San Diego. 205 p.

Conant, R. AND J. T. Collins. 1991. Reptiles and amphibians: eastern and central North America. Houghton Mifflin Co., Boston. $450 \mathrm{p}$.

Crossley, D. A., JR. 1977. The roles of saprophagous arthropods in forest soils: current status and concepts, p. 49-56. In: W. J. Mattson (ed.). The role of arthropods in forest ecosystems. Springer, New York.

DAvidson, J. A. 1956. Notes on the food habits of the slimy salamander Plethodon glutinosus glutinosus. Herpetologica, 12:129-131.

DOUGLAS, N. H. 1965. Observations on the predaceous and cannibalistic feeding habits of Eumeces laticeps Scheider. Herpetologica, 21:308-309.

EISENBEIS, G. AND W. WiCHARD. 1987. Atlas on the biology of soil arthropods. Springer-Verlag, Berlin. $437 \mathrm{p}$.

ECKSCMITT, K., V. WOLTERS AND M. WEBER. 1997. Spiders, carabids, and staphylinids: the ecological potential of predatory macroarthropods, p. 307-362. In: G. Benckiser (ed.). Fauna in soil ecosystems: recycling processes, nutrient fluxes, and agricultural production. Marcel Dekker, Inc., New York.

GibBons, J. W. AND R. SEMLITsCH. 1991. Guide to the reptiles and amphibians of the S.R.S. University of Georgia Press, Athens. 131 p.

GÜNTHER, K. AND K. HeRTER. 1974. Dermaptera (Ohrwürmer). Handb. Zool. Berlin, 4:1-158.

Hamilton, W. J. 1932. The food and feeding habits of eastern salamanders. Copeia, 1932:83-86.

HAMilton, W. J., JR. 1955. Notes on the ecology of the oak toad in Florida. Herpetologica, 11:205-210

HANula, J. L. AND K. E. FranzReb. 1995. Arthropod prey of nestling Red-cockaded woodpeckers in the upper Coastal Plain of South Carolina. Wilson Bull., 107:485-495.

HEALY, W. 1953. Notes on the feeding habits of Thamnophis s. sirtalis in captivity. Herpetologica, 9:163. Holman, J. A. 1955. Fall and winter food of Plethodon dorsalis. Copeia, 1955:143.

- 1958. An interesting feeding activity of Microhyla carolinensis. Herpetologica, 14:205.

HinZPETER, U. AND T. BAUER. 1986. The antennal setal trap of the ground beetle Loricera pilicomis. a specialization for feeding on Collembola. $J$. Zool. (London), A208:615-630. 
HölLDOBLER, B. AND E.O. WiLsON. 1994. Journey to the ants: A story of scientific exploration. Bellknap Press, Cambridge. 228 p.

Hudson, R. G. 1947. Ophiophagous young black snakes. Herpetologica, 3(5):178.

Hunt, H. W., D. C. Coleman, E. R. Ingham, R. E. Ingham and E. T. Elliott. 1987. The detrital food web in a short grass prairie. Biol. Fertil. Soils, 3:57-68.

InGHam, E. R., D. C. Coleman AND J. C. Moore. 1989. An analysis of food-web structure and function in a shortgrass prairie, a mountain meadow, and a lodgepole pine forest. Biol. Fertil. Soils, 8: $29-37$.

Johnson, B. K. AND J. L. Christiansen. 1976. The food and habits of Blanchard's cricket frog, Acris crepitans blanchardi (Amphibia, Anura, Hylidae), in Iowa. J. Herpetol., 10:63-74.

Johnston, J. M. 1996. Microarthropod ecology in managed loblolly pine (Pinus taeda L.) forests: relations of oribatid diversity and arthropod community structure to management practices. Ph. D. Dissertation, University of Georgia, Athens. $160 \mathrm{p}$.

KajaK, A., K. Chmielewski, M. KaCzmarek And E. Rembialkowska. 1991. Experimental studies on the effect of epigeic predators on organic matter decomposition processes in managed peat grasslands. Pol. Ecol. Stud., 17:289-310.

KNIGHT, D. H. 1991. Pine forests: A comparative overview of ecosystem structure and function, p. 121135. In: N. Nakagoshi and F. B. Golley (eds.). Coniferous forest ecology from an international perspective. SPB Academic Publishing, The Hague.

LABANICK, G. M. 1976. Prey availability, consumption and selection in the cricket frog, Acris crepitans (Amphibia, Anura, Hylidae). J. Herpetol, 10:293-298.

MACNAMARA, M. C. 1977. Food habits of terrestrial adult migrants and immature red efts of the redspotted newt Notophthalmus viridescens. Herpetologica, 33:127-132.

Manley, G. V., J. W. BUtcher AND M. ZaRICK. 1976. DDT transfer and metabolism in a forest litter macro-arthropod food chain. Pedobiologia, 16:81--98.

MARTENS, J. 1978. Weberknechte, Opiliones. Die Tierwelt Deutschlands, 64:1-464.

Martof, B. S., W. M. Palmer, J. R. Bailey ANd J. R. Hafkison, III. 1980. Amphibians and reptiles of the Carolinas and Virginia. University of North Carolina Press, Chapel Hill. 264 p.

MasuKo, K. 1994. Specialized predation on Oribatid mites by two species of the ant genus Myrmecina (Hymenoptera: Formicidae). Psyche, 101:159-173.

MCMillan, M. A. AND R. D. Semlitsch. 1980. Prey of the dwarf salamander Eurycea quadridigitata in South Carolina. J. Herpetol., 14:424-426.

MOORE, J. C., D. E. Walter and H. W. Hunt. 1988. Arthropod regulation of micro- and mesobiota in below-ground detrital food webs. Annu. Rev. Eniomol., 33:419-39.

Moulder, B. C. AND D. E. ReICHLE. 1972. Significance of spider predation in the energy dynamics of forest-floor arthropod communities. Ecol. Monogr, 42:473-498.

NeNTWTG, W. (ed.) 1987. Ecophysiology of spiders. Springer, Berlin. 448 p.

NORTON, R. A. 1973. Ecology of soil and litter spiders, p. 138-156. In: D. L. Dindal (ed.). Proceedings of the first soil microcommunities conference. National Technical Information Service, Springfield, VA.

Norton, R. A. AND M. G. MACNAmARA. 1976. The common newt (Notophthalmus viridescens) as a predator of soil mites in New York. J. Ga. Entomol. Soc., 11:89-93.

ORLEB, E. 1951. Thamnophis sirtalis sirtalis eats Anolis carolinensis. Herpetologica, 7:76.

PARK, O. 1947. Observations on Batrisodes (Coleoptera: Pselaphidae), with particular reference to the American species east of the Rocky Mountains. Bull. Chicago Acad. Sci., 8:43-132.

PEARSON, P. G. 1955. Population ecology of the spadefoot toad, Scaphiophus h. holbrookii (Harlan). Ecol. Monogr, 25:233-267.

POWDERS, V. N. AND R. CATE. 1980. Food of the dwarf salamander, Eurycea quadridigitata, in Georgia. J. Herpetol., 14:82-83.

AND W. L. TIETJEN. 1974. The comparative food habits of sympatric and allopatric salamanders Plethodon glutinosus and Plethodon jordani in eastern Tennessee and adjacent areas. Herpetologica, 30:167-175. 
Reichle, D. E. AND D. A. Crossley, JR. 1965. Radiocesium dispersion in a cryptozoan food web. Health Physics, 11:1375-1384.

RIHA, G. 1951. Zür ökologie der oribatiden in kalksteinböden. Zool. Jb. Syst., 80:408-450.

Roth-HolzAPfEL, M. 1990. Multi-element analysis of invertebrate animals in a forest ecosystem (Picea abies L.), p. 281-295. In: H. Lieth and B. Markert (eds.). Element concentration cadasters in ecosystems: methods of assessment and evaluation. VCH Publishers, Weinheim.

SchaAF, R. T. AND J. S. GARTON. 1970. Raccoon predation on the American toad Bufo americanus. Herpetologica, 26:334-335.

SChERNEy, F. 1959. Unsere Laufkäfer, A. Ziemsen Verlag, Wittenberg-Lutherstadt. 245 p.

—. 1961. Beiträge zur Biologie und ökonomischer Bedeutung räuberisch lebender Käferarten. Beobachtungen und Versuche zur Überwinterung, Aktivität und Ernährungsweise der Laufkäfer (Carabidae). Z. Angew. Entomol., 48:163-175.

Schuster, R. 1966a. Über den Beutefang des Ameisenkäfers Cephennium austriacum Reiter. Naturwissenschaften, 53:113.

1966b. Scydmaeniden-Larven als Milbenriuber. Naturwissenschaften, 53:439-440.

Simon, H. R. 1964. Zur Ernihrungsbiologie collembolenfangender Arthropoden. Biol. Zentbl., 83:273296.

Simon, M. P. AND C. A. ToFT. 1991. Diet specialization in small vertebrates: mite-eating in frogs. Oikos, 61:263-278.

Singer, F. J., W. T. Swank and E. E. C. Clebsch. 1984. Effects of wild pig rooting in a deciduous forest. J. Wildl. Manage., 48:464-473.

Skeen, J. N., P. D. Doerr and D. H. VAN Lear. 1993. Oak-hickory-pine forests, p. I-33. In: W. H. Martin, S. G. Boyce and A. C. Echternacht (eds.). Biodiversity of the Southeastern United States: Upland terrestrial communities. John Wiley and Sons, Inc., New York.

Summerhayes, V. S. AND C. S. ETtON. 1923. Contributions to the ecology of Spitsbergen and Bear Island. J. Ecol., 11:214-286.

Sunderland, K. D., A. M. Fraser and A. F. G. Dixon. 1986. Distribution of linyphiid spiders in relation to capture of prey in cereal fields. Pedobiologia, 29:367-375.

TAVAres-Cromar, A. F. AND D. D. Williams. 1996. The importance of temporal resolution in food web analysis: evidence from a detritus-based stream. Ecol. Monogr, 66:91-113.

Van Pelt, A. F. 1966. Activity and density of old-field ants of the Savannah River Plant, South Carolina. J. Elisha Mitchell Sci. Soc., May:35-43.

-AND J. B. GentRY. 1985. The ants (Hymenoptera: Formicidae) of the Savannah River Plant, South Carolina. SRO-NERP-14.

VITT, L. J. AND W. E. COOPER. 1986. Foraging and diet of a diurnal predator (Eumeces laticeps) feeding on hidden prey. J. Herpetol., 20:408-415.

WARDLE, D. A. AND G. W. YEATES. 1993. The dual importance of competition and predation as regulatory forces in terrestrial ecosystems: Evidence from decomposer food webs. Oecologia, 93: 303-306.

WISE, D. H. 1993. Spiders in ecological webs. Cambridge University Press, Cambridge. 328 p.

Wood, J. T. 1948. Microhyla c. carolinensis in an ant nest. Herpetologica, 4:226. 